\title{
The role of silver on the stabilization of the incommensurately modulated structure in calaverite, $\mathrm{AuTe}_{2}$
}

\author{
LUCA Bindi, ${ }^{1, *}$ Alla ArakCheeva, ${ }^{2}$ AND Gervais Chapuis ${ }^{2}$
}

\author{
${ }^{1}$ Museo di Storia Naturale, Sezione di Mineralogia, Università di Firenze, Via La Pira 4, I-50121 Firenze, Italy \\ ${ }^{2}$ École Polytechnique Fédérale de Lausanne, Laboratoire de Cristallographie, BSP, CH-1015 Lausanne, Switzerland
}

\begin{abstract}
Structural investigations of several minerals belonging to the calaverite group with composition $\mathrm{Au}_{1-\mathrm{x}} \mathrm{Ag}_{\mathrm{x}} \mathrm{Te}_{2}(\mathrm{x}=0.00,0.02,0.05,0.09,0.19$, and 0.33$)$ indicate that $\mathrm{Ag}$ is randomly distributed on the Au sites. This suppresses the valence fluctuation of $\mathrm{Au}$ and, therefore, the structure modulations. The results are compared with the previously published incommensurately modulated structure of calaverite, $\mathrm{Au}_{0.9} \mathrm{Ag}_{0.1} \mathrm{Te}_{2}$, which is characterized by valence fluctuations of $\mathrm{Au}$ reinforced by an ordered distribution of $\mathrm{Ag}$. The (3+1)-dimensional calaverite structure type is able to reproduce both $(3+1) \mathrm{D}$ and $3 \mathrm{D}$ related structures with the general formula $\mathrm{AB}_{2}(\mathrm{~A}=\mathrm{Au}, \mathrm{Ag}, \mathrm{Cu}, \mathrm{Nb}, \mathrm{Ta} ; \mathrm{B}=\mathrm{Te})$.
\end{abstract}

Keywords: Calaverite, modulated structure, valence fluctuations, krennerite

\section{INTRODUCTION}

Calaverite was first identified by Ghent (1861) and, since its discovery, it has been the subject of numerous studies, in large part because of the difficulties mineralogists encountered in indexing crystalline specimens from different locations. It was later found that the diffraction pattern of calaverite exhibited satellite reflections, which pointed to the presence of an incommensurately modulated structure (Chapuis 2003 and references therein). Calaverite belongs to the group of gold-silver tellurides with the chemical formula $\mathrm{Au}_{1-x} \mathrm{Ag}_{\mathrm{x}} \mathrm{Te}_{2}$, the most important group of minerals from an economic standpoint in the $\mathrm{Au}-\mathrm{Ag}$ - $\mathrm{Te}$ system. This group comprises calaverite, $\mathrm{AuTe}_{2}$ (the monoclinic polymorph); krennerite, $\mathrm{AuTe}_{2}$ (the orthorhombic polymorph); and sylvanite, $\mathrm{AuAgTe} 4$. Based on the experimental data of Cabri (1965), calaverite, krennerite, and sylvanite contain 0.00 to 2.8 $\mathrm{wt} \%, 3.4$ to $6.2 \mathrm{wt} \%$, and 6.7 to $13.2 \mathrm{wt} \% \mathrm{Ag}$, respectively. These minerals occur in several epizonal and mesozonal gold and gold-silver telluride deposits including the Golden Mile, Kalgoorlie, Australia (e.g., Clout et al. 1990; Shackleton et al. 2003), Emperor, Fiji (e.g., Ahmad et al. 1987; Pals and Spry 2003), Cripple Creek, Colorado (e.g., Thompson et al. 1985), and Săcărîmb, Romania (Alderton and Fallick 2000) deposits, which are among the largest gold deposits in the world.

From the crystallographic standpoint, calaverite has received much attention in the past century because its morphology was considered to violate Haüy's law of rational indices (Goldschmidt et al. 1931 and references therein). It is surprising that the introduction of diffraction techniques did not solve the puzzle initially. Indeed, it was first Tunell and Ksanda (1936) and then Tunell and Pauling (1952) who were able to solve the average $C 2 / m$ structure of calaverite. However, they did not propose any interpretation of the so-called "adventive diffraction spots" (now called satellites) observed in the diffraction pattern of calaverite.

*E-mail: luca.bindi@unifi.it
Sueno et al. (1979) were the first to identify the additional spots as "wavy displacements" in the structure. These authors found that the satellite positions were at $27.3^{\circ}$ from the $+\mathbf{c}^{*}$ axis and

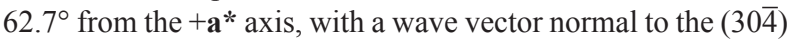
lattice plane. Nonetheless, Sueno et al. (1979) could not solve the structure with a sinusoidal wave-distribution function for the displacement of the Te atoms in a commensurate enlarged supercell. Later, based on a transmission electron microscopy (TEM) study, Van Tendeloo et al. (1983a) pointed out that the satellite reflections in calaverite were due to an incommensurately displacive modulation superimposed on the average $C 2 / m$ structure. Using the information gained from the TEM study, Dam et al. (1985) were able to clarify the morphology of calaverite by indexing the crystal faces with four instead of three indices, the extra index applying to $\mathbf{q}=-0.4095 \mathbf{a} *+0.4492 \mathbf{c} *$. Finally, Schutte and de Boer (1988), using the superspace approach, solved the incommensurately modulated structure of calaverite in the superspace group $C 2 / m(\alpha 0 \gamma) 0 s$. These authors showed that the modulation consists mainly of displacements of Te atoms and the observed modulations are interpreted in terms of valence fluctuations between $\mathrm{Au}^{+}$and $\mathrm{Au}^{3+}$. More recently, Balzuweit et al. (1993) studied the variation of the modulation wave vector in synthetic calaverite as a function of temperature and silver content (up to $3.0 \mathrm{at} \%$ of $\mathrm{Ag}$ ) using $\mathrm{X}$-ray diffraction and morphological techniques.

In the course of research projects dealing with the characterization of tellurium-bearing minerals from museum collections (Bindi and Cipriani 2003a, 2003b, 2004a, 2004b, 2004c, 2004d; Bindi et al. 2004, 2005; Bindi 2008, 2009), we analyzed calaverite samples with variable silver contents. The aim of the present work is to characterize calaverite by single-crystal X-ray diffraction, scanning electron microscopy (SEM), and electron probe microanalysis (EPMA) and to discuss the role of silver in the stabilization of the incommensurately modulated structure in the framework of the superspace concept. 


\section{OCCURRENCE, PHYSICAL AND OPTICAL PROPERTIES}

A list of the samples investigated in this study, together with their locations and chemical formulae, is given in Table 1. All the samples came from the mineralogical collection of the Museo di Storia Naturale, Università di Firenze. The calaverite samples have colors ranging from yellow to silver white, show a greenish to yellowish gray streak and exhibit a metallic luster. The crystals are brittle and their fractures are uneven to subconchoidal. Micro-indentation measurements carried out with a VHN load of $100 \mathrm{~g}$ give the mean values reported in Table 2 .

In plane-polarized incident light, calaverite is white in color, with moderate bireflectance (from white to brownish gray). Under crossed polars, calaverite shows weak anisotropism without internal reflections. Reflectance measurements were performed for all the samples in air by means of a MPM-200 Zeiss microphotometer equipped with a MSP-20 system processor on a Zeiss Axioplan ore microscope. The filament temperature was approximately $3350 \mathrm{~K}$. An interference filter was adjusted to select, in turn, four wavelengths for measurement (471.1, 548.3, 586.6 , and $652.3 \mathrm{~nm}$ ). Readings were taken for the specimen and standard (SiC) under the same focus conditions. The diameter of the circular measuring area was $0.1 \mathrm{~mm}$. Reflectance percentages for $R_{\min }$ and $R_{\max }$ are given in Table 3. It appears that the reflectivity values decrease with the increase of silver replacing gold.

\section{Chemical composition}

Qualitative chemical analysis using energy dispersive spectrometry, performed on the crystal fragments used for the structural study, did not indicate the presence of elements $(Z>9)$ other than $\mathrm{Ag}, \mathrm{Au}$, and Te. Quantitative chemical compositions were then determined using wavelength dispersive analysis (WDS) by means of a JEOL JXA-8600 electron microprobe. Concentrations of major and minor elements were determined at an accelerating voltage of $20 \mathrm{kV}$ and a beam current of $40 \mathrm{nA}$, with $10 \mathrm{~s}$ as the counting time. For the WDS analyses, the following lines were used: $\operatorname{Ag} L \alpha, \operatorname{Au} M \alpha$, and $\operatorname{Te} L \alpha$. The standards employed were

TABLE 1. List of the calaverite samples studied

\begin{tabular}{llll}
\hline Sample & Label & \multicolumn{1}{c}{ Provenance } & Chemical formula \\
\hline 2400/l & $\mathrm{Ag}_{0.00}$ & Kotchbulak, Uzbekistan & $\mathrm{Au}_{0.99} \mathrm{Te}_{2.01}$ \\
48028/G & $\mathrm{Ag}_{0.02}$ & Kalgoorlie, Australia & $\left(\mathrm{Au}_{0.97} \mathrm{Ag}_{0.02}\right) \mathrm{Te}_{2.01}$ \\
$898 / \mathrm{G}$ & $\mathrm{Ag}_{0.05}$ & Colorado, U.S.A. & $\left(\mathrm{Au}_{0.95} \mathrm{Ag}_{0.05}\right) \mathrm{Te}_{2.00}$ \\
894/G & $\mathrm{Ag}_{0.09}$ & Nagyag, Transylvania, Romania & $\left(\mathrm{Au}_{0.90} \mathrm{Ag}_{0.09}\right) \mathrm{Te}_{2.01}$ \\
884/G & $\mathrm{Ag}_{0.19}$ & Offenbanya, Transylvania, Romania & $\left(\mathrm{Au}_{0.83} \mathrm{Ag}_{0.19}\right) \mathrm{Te}_{1.98}$ \\
885/G & $\mathrm{Ag}_{0.33}$ & Offenbanya, Transylvania, Romania & $\left(\mathrm{Au}_{0.68} \mathrm{Ag}_{0.33}\right) \mathrm{Te}_{1.99}$ \\
\hline
\end{tabular}

TABLE 2. Mean microhardness $\left(\mathrm{kg} / \mathrm{mm}^{2}\right)$ values for the calaverite samples investigated

\begin{tabular}{lcc}
\hline Sample & Mean value & Range \\
\hline $\mathrm{Ag}_{0.00}$ & 169 & $160-175$ \\
$\mathrm{Ag}_{0.02}$ & 180 & $172-187$ \\
$\mathrm{Ag}_{0.05}$ & 189 & $180-194$ \\
$\mathrm{Ag}_{0.09}$ & 194 & $188-199$ \\
$\mathrm{Ag}_{0.19}$ & 197 & $192-204$ \\
$\mathrm{Ag}_{0.33}$ & 199 & $193-207$ \\
\hline
\end{tabular}

native elements for $\mathrm{Ag}, \mathrm{Au}$, and $\mathrm{Te}$. The crystal fragments were found to be homogeneous within the analytical errors. The average chemical compositions (six to eight analyses on each grain) are reported in Table 4 . The chemical formulae were calculated on the basis of three atoms.

\section{Single-crystal X-ray diffraction}

The diffraction quality of the single crystals was initially checked by means of an Enraf-Nonius CAD4 single crystal diffractometer equipped with a conventional point detector. The crystals were then carefully investigated using an Oxford Diffraction "Xcalibur 3" single-crystal diffractometer (enhanced $\mathrm{X}$-ray source, $\mathrm{X}$-ray radiation $\mathrm{Mo} K \alpha, \lambda=0.71073 \AA$ ) fitted with a Sapphire 2 CCD detector. A total of 500 frames of data were collected $^{1}$ for each crystal at room temperature consisting of 5 sets of omega runs with an exposure time of $30 \mathrm{~s}$ per frame and a frame width of $0.75^{\circ}$. Data frames were processed using the CrysAlis software package (Oxford Diffraction 2006) running on the Xcalibur 3 control PC. A relatively high $\sin (\theta) / \lambda$ cut off and a high redundancy were chosen in the recording settings. Unit-cell parameters for the selected crystals are given in Table 5. The modulation wave vectors (Table 6 ) were obtained by the least-squares refinement of the setting angles of the first-order satellites along with the main reflections. Only first-order satellites could be observed after integration for $\mathrm{Ag}_{0.09}, \mathrm{Ag}_{0.05}, \mathrm{Ag}_{0.02}$, and $\mathrm{Ag}_{0.00}$. No satellites have been detected for the Ag-rich members. Other crystals tested from the different samples (3-4 for each sample) gave similar results both in terms of observed

${ }^{1}$ Deposit item AM-09-025, CIFs. Deposit items are available two ways: For a paper copy contact the Business Office of the Mineralogical Society of America (see inside front cover of recent issue) for price information. For an electronic copy visit the MSA web site at http://www.minsocam.org, go to the American Mineralogist Contents, find the table of contents for the specific volume/issue wanted, and then click on the deposit link there.

TABLE 4. Electron microprobe analyses (means and ranges in wt $\%$ of elements) and atomic ratios (calculated on the basis of 3 atoms) of the selected calaverite crystals

\begin{tabular}{|c|c|c|c|c|c|c|}
\hline & $\mathrm{Ag}_{0.00}$ & Ranges & $\mathrm{Ag}_{0.02}$ & Ranges & $\mathrm{Ag}_{0.05}$ & Ranges \\
\hline $\mathrm{Au}$ & 42.94 & $(42.63-43.40)$ & 42.43 & (42.09-42.99) & 41.70 & (41.33-42.07) \\
\hline $\mathrm{Ag}$ & - & $(0.00-0.03)$ & 0.48 & $(0.35-0.60)$ & 1.20 & (1.11-1.36) \\
\hline $\mathrm{Te}$ & 56.47 & $(56.00-57.12)$ & 56.94 & (56.05-57.58) & 56.87 & (56.64-57.39) \\
\hline Tota & 99.41 & (99.13-100.22) & 99.85 & (99.65-100.44) & 99.77 & $(99.42-100.51)$ \\
\hline $\mathrm{Au}$ & 0.99 & & 0.97 & & 0.95 & \\
\hline $\mathrm{Ag}$ & - & & 0.02 & & 0.05 & \\
\hline \multirow[t]{2}{*}{$\mathrm{Te}$} & 2.01 & & 2.01 & & 2.00 & \\
\hline & $\mathrm{Ag}_{0.09}$ & Ranges & $\mathrm{Ag}_{0.19}$ & Ranges & $\mathrm{Ag}_{0.33}$ & Ranges \\
\hline $\mathrm{Au}$ & 40.05 & (39.66-40.25) & 37.63 & $(37.25-38.03)$ & 31.60 & $(31.25-32.34)$ \\
\hline $\mathrm{Ag}$ & 2.19 & $(1.95-2.30)$ & 4.69 & $(4.50-4.81)$ & 8.40 & $(8.11-8.60)$ \\
\hline Te & 57.96 & $(57.60-58.23)$ & 57.84 & $(57.44-58.12)$ & 59.90 & (59.45-60.23) \\
\hline Tota & 100.20 & (99.32-100.66) & 100.16 & (99.17-100.42) & 99.90 & $(99.42-100.01)$ \\
\hline $\mathrm{Au}$ & 0.90 & & 0.83 & & 0.68 & \\
\hline $\mathrm{Ag}$ & 0.09 & & 0.19 & & 0.33 & \\
\hline Te & 2.01 & & 1.98 & & 1.99 & \\
\hline
\end{tabular}

TABLE 3. $R_{\min }$ and $R_{\max }$ values (\%) for the calaverite samples investigated

\begin{tabular}{lcccccc}
\hline Wavelength $(\mathrm{nm})$ & $\mathrm{Ag}_{0.00}$ & $\mathrm{Ag}_{0.02}$ & $\mathrm{Ag}_{0.05}$ & $\mathrm{Ag}_{0.09}$ & $\mathrm{Ag}_{0.19}$ & $\mathrm{Ag}_{0.33}$ \\
\hline 471.1 & $56.2-61.8$ & $56.0-61.3$ & $55.7-61.0$ & $54.3-60.2$ & $53.0-56.8$ & $50.1-53.8$ \\
548.3 & $61.2-66.3$ & $60.9-65.9$ & $60.3-65.1$ & $59.5-64.2$ & $58.3-63.0$ & $56.2-60.9$ \\
586.6 & $63.2-68.0$ & $63.0-67.5$ & $62.3-67.2$ & $61.5-66.2$ & $60.1-65.4$ & $57.2-62.7$ \\
652.3 & $65.4-69.8$ & $65.1-69.6$ & $64.7-69.3$ & $64.1-68.5$ & $63.1-67.0$ \\
\hline
\end{tabular}


TABLE 5. Unit-cell parameters for the selected calaverite crystals

\begin{tabular}{lccccc}
\hline Sample & $a(\AA)$ & $b(\AA)$ & $c(\AA)$ & $\beta\left({ }^{\circ}\right)$ & $V\left(\AA^{3}\right)$ \\
\hline $\mathrm{Ag}_{0.00}$ & $7.1901(5)$ & $4.4077(3)$ & $5.0701(4)$ & $90.037(2)$ & $160.68(2)$ \\
$\mathrm{Ag}_{0.02}$ & $7.1945(5)$ & $4.4101(3)$ & $5.0790(5)$ & $90.035(2)$ & $161.15(2)$ \\
$\mathrm{Ag}_{0.05}$ & $7.2115(5)$ & $4.4123(2)$ & $5.0912(5)$ & $90.028(2)$ & $162.00(2)$ \\
$\mathrm{Ag}_{0.09}$ & $7.2356(4)$ & $4.4160(3)$ & $5.1112(4)$ & $90.030(3)$ & $163.32(2)$ \\
$\mathrm{Ag}_{0.19}$ & $7.2998(5)$ & $4.4250(3)$ & $5.1563(4)$ & $90.032(3)$ & $166.56(2)$ \\
$\mathrm{Ag}_{0.33}$ & $7.4002(4)$ & $4.4366(2)$ & $5.2416(5)$ & $90.034(2)$ & $172.09(2)$ \\
\hline
\end{tabular}

TABLE 6. Modulation wave vectors for the selected calaverite crystals

\begin{tabular}{lc}
\hline Sample & Modulation wave vector \\
\hline $\mathrm{Ag}_{0.00}$ & $-0.4026(2) \mathbf{a}^{*}+0.4470(2) \mathbf{c}^{*}$ \\
$\mathrm{Ag}_{0.02}$ & $-0.4051(2) \mathbf{a}^{*}+0.4479(2) \mathbf{c}^{*}$ \\
$\mathrm{Ag}_{0.05}$ & $-0.4071(3) \mathbf{a}^{*}+0.4491(3) \mathbf{c}^{*}$ \\
$\mathrm{Ag}_{0.09}$ & $-0.4112(2) \mathbf{a}^{*}+0.4511(2) \mathbf{c}^{*}$ \\
$\mathrm{Ag}_{0.19}$ & - \\
$\mathrm{Ag}_{0.33}$ & - \\
\hline
\end{tabular}

satellites and modulation wave vectors. In an attempt to detect observable satellites for the Ag-rich members, a second measurement was performed with longer exposure times ( $400 \mathrm{~s})$. No appreciable time-dependent change in intensities and/or positions of both main and satellite reflections was observed. A similar result was obtained when the same crystals were collected at a temperature ca. $110 \mathrm{~K}$, the low temperature being achieved by means of an Oxford cryostream cooler. Before measurement, the samples were held at the specified temperature for about 180 $\min$. After the cooling experiment, the crystals were re-heated to ca. $300 \mathrm{~K}$, and new data were collected. The obtained unit-cell parameter and modulation wave vectors did not reveal significant variation from the previous ones. Intensity integration and standard Lorentz-polarization correction were performed with the CrysAlis RED (Oxford Diffraction 2006) software package. The program ABSPACK in CrysAlis RED was applied for the absorption correction. The least-squares program JANA2006 (Petŕíček et al. 2006) was used for the refinements of all the structures. Neutral scattering curves for $\mathrm{Au}, \mathrm{Ag}$, and $\mathrm{Te}$ were taken from the International Tables for X-ray Crystallography (Ibers and Hamilton 1974). Refinements of the incommensurately modulated structures were performed in the superspace group $C 2 / m(\alpha 0 \gamma) 0 s$ for $\mathrm{Ag}_{0.00}, \mathrm{Ag}_{0.02}, \mathrm{Ag}_{0.05}$, and $\mathrm{Ag}_{0.09}$ and in the space group $C 2 / m$ for $\mathrm{Ag}_{0.19}$ and $\mathrm{Ag}_{0.33}$ (no satellites detected). Experimental details of the data collections and refinements are given in Table 7. Fractional atomic coordinates, anisotropic displacement parameters, and selected bond distances are reported in Tables 8-11.

The incommensurately modulated structures of $\mathrm{Ag}_{0.00}, \mathrm{Ag}_{0.02}$, $\mathrm{Ag}_{0.05}$, and $\mathrm{Ag}_{0.09}$ have been refined according to the following scheme: first, the average structure was refined. Then the first harmonic of positional modulation wave was introduced for both $\mathrm{Te}$ and (Au,Ag). The only possible amplitude of the (Au,Ag) positional modulation (Table 8) was equal to 0 within 1 standard deviation for $\mathrm{Ag}_{0.00}$ and $\mathrm{Ag}_{0.02}$ and within 2 standard deviations for $\mathrm{Ag}_{0.05}$ (Table 8). The refinement of the Te positional modulation improved all $R$ factors; however, the essential

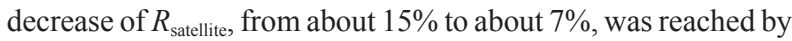
applying an additional crenel function ( 0.5 length along $t_{4}$ with the center at $\left.t_{4}=0.25\right)$ for $\mathrm{Ag}_{0.00}, \mathrm{Ag}_{0.02}$, and $\mathrm{Ag}_{0.05}$. This crenel function results in a small shift of Te from the mirror plane $\left[y_{\mathrm{Te}}\right.$ $\approx-0.04$ to -0.02 (Table 8 )]. The refined contributions of $\mathrm{Ag}$ in

TABLE 7. Data and experimental details for the selected calaverite crystals

\begin{tabular}{|c|c|c|c|c|c|c|}
\hline & $\mathrm{Ag}_{0.00}$ & $\mathrm{Ag}_{0.02}$ & $\mathrm{Ag}_{0.05}$ & $\mathrm{Ag}_{0.09}$ & $\mathrm{Ag}_{0.19}$ & $\mathrm{Ag}_{0.33}$ \\
\hline Temperature (K) & 298 & 298 & 298 & 298 & 298 & 298 \\
\hline Cell setting & monoclinic & monoclinic & monoclinic & monoclinic & monoclinic & monoclinic \\
\hline $\begin{array}{l}\text { Superspace group/ } \\
\text { Space group }\end{array}$ & $c 2 / m(a 0 \gamma) 0 s$ & $C 2 / m(a 0 \gamma) 0 s$ & $c 2 / m(a 0 \gamma) 0 s$ & $c 2 / m(a 0 \gamma) 0 s$ & $\mathrm{C} 2 / \mathrm{m}$ & $\mathrm{C} 2 / \mathrm{m}$ \\
\hline Crystal color & yellow & yellow & yellow & yellow & yellow & yellow \\
\hline Crystal shape & irregular & irregular & irregular & irregular & irregular & irregular \\
\hline Crytal size (mm) & $0.11 \times 0.12 \times 0.13$ & $0.09 \times 0.10 \times 0.13$ & $0.08 \times 0.09 \times 0.11$ & $0.10 \times 0.10 \times 0.12$ & $0.07 \times 0.09 \times 0.10$ & $0.07 \times 0.11 \times 0.12$ \\
\hline Diffractometer & $\begin{array}{l}\text { Oxford } \\
\text { Diffraction } \\
\text { Xcalibur } 3\end{array}$ & $\begin{array}{l}\text { Oxford } \\
\text { Diffraction } \\
\text { Xcalibur } 3\end{array}$ & $\begin{array}{l}\text { Oxford } \\
\text { Diffraction } \\
\text { Xcalibur } 3\end{array}$ & $\begin{array}{l}\text { Oxford } \\
\text { Diffraction } \\
\text { Xcalibur } 3\end{array}$ & $\begin{array}{l}\text { Oxford } \\
\text { Diffraction } \\
\text { Xcalibur } 3\end{array}$ & $\begin{array}{l}\text { Oxford } \\
\text { Diffraction } \\
\text { Xcalibur } 3\end{array}$ \\
\hline Radiation & $\begin{array}{l}\text { MoK-L2,3 } \\
(0.71073 \AA)\end{array}$ & $\begin{array}{l}\text { MoK-L2,3 } \\
(0.71073 \AA)\end{array}$ & $\begin{array}{l}\text { MoK-L2,3 } \\
(0.71073 \AA)\end{array}$ & $\begin{array}{l}\text { MoK-L2,3 } \\
(0.71073 \AA)\end{array}$ & $\begin{array}{l}\text { MoK-L2,3 } \\
(0.71073 \AA)\end{array}$ & $\begin{array}{l}\text { MoK-L2,3 } \\
(0.71073 \AA)\end{array}$ \\
\hline Monochromator & graphite & graphite & graphite & graphite & graphite & graphite \\
\hline Scan mode & $\varphi / \omega$ & $\varphi / \omega$ & $\varphi / \omega$ & $\varphi / \omega$ & $\varphi / \omega$ & $\varphi / \omega$ \\
\hline $\begin{array}{l}\text { Detector to sample } \\
\text { distance }(\mathrm{cm})\end{array}$ & 5 & 5 & 5 & 5 & 5 & 5 \\
\hline Measuring time (s) & 30 & 30 & 30 & 30 & 30 & 30 \\
\hline Theta range $\left({ }^{\circ}\right)$ & $1-45$ & $1-45$ & $1-45$ & $1-45$ & $1-45$ & $1-45$ \\
\hline Range of $h, k, l, m$ & $\begin{array}{l}-14 \leq h \leq 14 \\
-8 \leq k \leq 8 \\
-10 \leq l \leq 10 \\
-1 \leq m \leq 1\end{array}$ & $\begin{array}{l}-14 \leq h \leq 14 \\
-8 \leq k \leq 8 \\
-10 \leq l \leq 10 \\
-1 \leq m \leq 1\end{array}$ & $\begin{array}{l}-14 \leq h \leq 14 \\
-8 \leq k \leq 8 \\
-10 \leq l \leq 10 \\
-1 \leq m \leq 1\end{array}$ & $\begin{array}{l}-14 \leq h \leq 14 \\
-8 \leq k \leq 8 \\
-10 \leq l \leq 10 \\
-1 \leq m \leq 1\end{array}$ & $\begin{array}{l}-14 \leq h \leq 14 \\
-8 \leq k \leq 8 \\
-10 \leq l \leq 10 \\
-1 \leq m \leq 1\end{array}$ & $\begin{array}{l}-14 \leq h \leq 14 \\
-8 \leq k \leq 8 \\
-10 \leq l \leq 10 \\
-1 \leq m \leq 1\end{array}$ \\
\hline No. of measured refl. & 5289 & 5312 & 5302 & 5344 & 5401 & 5398 \\
\hline No. of unique refl. & 788 & 756 & 751 & 746 & 738 & 727 \\
\hline No. of observed refl. & 698 & 678 & 677 & 681 & 684 & 651 \\
\hline Criterion for obs. & $I>3 \sigma(I)$ & $I>3 \sigma(I)$ & $I>3 \sigma(I)$ & $I>3 \sigma(I)$ & $I>3 \sigma(I)$ & $I>3 \sigma(I)$ \\
\hline$R_{\text {int }}$ & 0.057 & 0.105 & 0.037 & 0.064 & 0.039 & 0.056 \\
\hline Refinement coefficient & $F$ & $F$ & $F$ & $F$ & $F$ & $F$ \\
\hline No. of refined parameters & 34 & 34 & 35 & 35 & 13 & 13 \\
\hline Weighting scheme & $\begin{array}{l}w=1 /\left[\sigma^{2}(F)^{2}+\right. \\
\left(0.0001(F)^{2}\right]\end{array}$ & $\begin{array}{l}w=1 /\left[\sigma^{2}(F)^{2}+\right. \\
\left(0.0001(F)^{2}\right]\end{array}$ & $\begin{array}{l}w=1 /\left[\sigma^{2}(F)^{2}+\right. \\
\left(0.0001(F)^{2}\right]\end{array}$ & $\begin{array}{l}w=1 /\left[\sigma^{2}(F)^{2}+\right. \\
\left(0.0001(F)^{2}\right]\end{array}$ & $\begin{array}{l}w=1 /\left[\sigma^{2}(F)^{2}+\right. \\
\left(0.0001(F)^{2}\right]\end{array}$ & $\begin{array}{l}w=1 /\left[\sigma^{2}(F)^{2}+\right. \\
\left(0.0001(F)^{2}\right]\end{array}$ \\
\hline$R, w R$ (all reflections) & $0.0479,0.0579$ & $0.0383,0.0385$ & $0.0326,0.0327$ & $0.0426,0.0551$ & $0.0230,0.0235$ & $0.0189,0.0197$ \\
\hline$R, w R$ (main reflections) & $0.0470,0.0544$ & $0.0365,0.0366$ & $0.0313,0.0314$ & $0.0421,0.0538$ & $0.0230,0.0235$ & $0.0189,0.0197$ \\
\hline$R, w R$ (satellites) & $0.0751,0.0929$ & $0.0764,0.0767$ & $0.0676,0.0677$ & $0.0931,0.1163$ & - & - \\
\hline Diff. Fourier $\left(\mathrm{e}^{-} / \AA^{3}\right)$ & {$[-0.38,0.38]$} & {$[-0.05,0.05]$} & {$[-0.01,0.01]$} & {$[-0.35,0.28]$} & {$[-0.27,0.31]$} & {$[-0.18,0.22]$} \\
\hline
\end{tabular}


TABLE 8. Final values of coordinates and Fourier amplitudes of the displacive modulation functions and equivalent isotropic displacement parameters $\left(\AA^{2}\right)$

\begin{tabular}{|c|c|c|c|c|c|c|}
\hline & Occupancy & Wave & $x$ & $y$ & $z$ & $U_{\text {iso }}$ \\
\hline \multicolumn{7}{|c|}{$\mathbf{A g}_{0.00}$} \\
\hline \multirow[t]{3}{*}{$\mathrm{Au}$} & $1.000 \mathrm{Au}$ & & 0 & 0 & 0 & $0.02352(9)$ \\
\hline & & $s, 1$ & 0 & 0 & 0 & \\
\hline & & $c, 1$ & 0 & 0 & 0 & \\
\hline \multirow[t]{4}{*}{ Te } & 1.000Te & & $0.6917(12)$ & $-0.024(4)$ & $0.295(3)$ & $0.035(2)$ \\
\hline & & $s, 1$ & $-0.0051(19)$ & $0.031(5)$ & $-0.012(4)$ & \\
\hline & & $c, 1$ & $0.0051(6)$ & $-0.0313(6)$ & $0.0105(11)$ & \\
\hline & \multicolumn{6}{|c|}{$\mathbf{A g}_{0.02}$} \\
\hline \multirow[t]{3}{*}{$\mathrm{Au}$} & $0.98 \mathrm{Au}+0.02 \mathrm{Ag}$ & & 0 & 0 & 0 & $0.02390(6)$ \\
\hline & & $\mathrm{s}, 1$ & 0 & 0 & 0 & \\
\hline & & $c, 1$ & 0 & 0 & 0 & \\
\hline \multirow[t]{4}{*}{ Te } & 1.000Te & & $0.6889(12)$ & $-0.035(4)$ & $0.290(2)$ & $0.029(3)$ \\
\hline & & $\mathrm{s}, 1$ & $-0.0008(19)$ & $0.043(6)$ & $-0.004(4)$ & \\
\hline & & $c, 1$ & $0.0050(8)$ & $-0.0283(5)$ & $0.0099(17)$ & \\
\hline & & & $\mathrm{Ag}_{0.05}$ & & & \\
\hline \multirow[t]{3}{*}{$\mathrm{Au}$} & $0.948(3) \mathrm{Au}+0.052 \mathrm{Ag}$ & & 0 & 0 & 0 & $0.02342(5)$ \\
\hline & & $s, 1$ & 0 & $-0.0012(6)$ & 0 & \\
\hline & & $c, 1$ & 0 & 0 & 0 & \\
\hline \multirow[t]{3}{*}{ Te } & 1.000Te & & $0.6886(9)$ & $-0.0448(3)$ & $0.2894(13)$ & $0.0303(11)$ \\
\hline & & $\mathrm{s}, 1$ & $-0.0009(13)$ & 0.0543 & $-0.003(2)$ & \\
\hline & & $c, 1$ & $0.0053(6)$ & $-0.0293(4)$ & $0.0099(10)$ & \\
\hline & & & $\mathrm{Ag}_{0.09}$ & & & \\
\hline \multirow[t]{3}{*}{$\mathrm{Au}$} & $0.908(8) \mathrm{Au}+0.092 \mathrm{Ag}$ & & 0 & 0 & 0 & $0.02235(16)$ \\
\hline & & $\mathrm{s}, 1$ & 0 & $0.0199(7)$ & 0 & \\
\hline & & $c, 1$ & 0 & 0 & 0 & \\
\hline \multirow[t]{3}{*}{ Te } & 1.000Te & & $0.68788(8)$ & 0 & $0.28710(11)$ & $0.03501(15)$ \\
\hline & & $\mathrm{s}, 1$ & 0 & $-0.0044(10)$ & 0 & \\
\hline & & $c, 1$ & 0 & $-0.0076(8)$ & 0 & \\
\hline \multicolumn{7}{|c|}{$\mathbf{A g}_{0.19}$} \\
\hline $\mathrm{Au}$ & $0.888(3) \mathrm{Au}+0.112 \mathrm{Ag}$ & & 0 & 0 & 0 & $0.02288(6)$ \\
\hline Te & 1.000Te & & $0.68692(5)$ & 0 & $0.28722(7)$ & $0.0324(1)$ \\
\hline \multicolumn{7}{|c|}{$\mathbf{A g}_{0.33}$} \\
\hline $\mathrm{Au}$ & $0.782(3) \mathrm{Au}+0.218 \mathrm{Ag}$ & & 0 & 0 & 0 & $0.02274(5)$ \\
\hline Te & 1.000Te & & $0.68552(3)$ & 0 & $0.28681(5)$ & $0.02951(7)$ \\
\hline
\end{tabular}

the (Au,Ag) position confirm the chemical analysis for $\mathrm{Ag}_{0.05}$ and $\mathrm{Ag}_{0.09}$. For $\mathrm{Ag}_{0.02}$, the $\mathrm{Ag}$ value was fixed at 0.02 because of its uncertainty, which was equal to the value of the $\mathrm{Ag}$ contribution, i.e., 0.02(2). Refinement of the ordered distribution of Ag on the $\mathrm{Au} / \mathrm{Ag}$ position is not justified following the absence of secondorder satellites, which should appear as a result of the occupation modulations (Schutte and de Boer 1988). Refinement of the ADP modulations (Table 9 ) improved all the $R$ factors.

The refinement of $\mathrm{Ag}_{0.19}$ and $\mathrm{Ag}_{0.33}$ did not present any problem. Nevertheless, in both cases the refined occupancies for silver in the (Au,Ag) positions yielded lower Ag contents in comparison to those obtained by electron microprobe analyses [refined values: 0.112(3)Ag and 0.218(3)Ag for $\mathrm{Ag}_{0.19}$ and $\mathrm{Ag}_{0.33}$, respectively].

\section{Discussion}

\section{Crystal chemistry and structure modulations}

The crystal structure of calaverite (Pertlik 1984a; Schutte and de Boer 1988; Reithmayer et al. 1993) is represented in Figure 1. It is based on a distorted hexagonal closed-packed array of $\mathrm{Te}^{2-}$ anions with $\mathrm{Au}$ (and Ag) cations occupying the octahedral sites. $\mathrm{AuTe}_{6}$ octahedra form sheets parallel to (001) that are linked by Te-Te bonds.

The refinement of the site-occupancy factor of the (Au,Ag) position in all the investigated calaverite crystals indicates that $\mathrm{Ag}$ randomly substitutes for $\mathrm{Au}$ in the octahedral site. A strong differentiation of the (Au,Ag)-Te distances is observed for all the samples independently of the compositions. Two distances are essentially shorter than the other four (Tables 10 and 11; Fig. 2, left), so that the coordination number $(\mathrm{CN})$ of $(\mathrm{Au}, \mathrm{Ag})$ can be generally considered as $\mathrm{CN}=2$ +4 . The mean bond distances range from $2.87 \AA$ in $\mathrm{Ag}_{0.00}$ to $2.93 \AA$ in $\mathrm{Ag}_{0.33}$. This increase is not uniform and reflects mainly the two shortest distances, which vary from 2.67 to $2.77 \AA$, while the mean value of the other four distances changes by only 0.04 $\AA$, from 2.97 to $3.01 \AA$, with increasing the amounts of Ag (Fig. 2 , left). The two short distances remain nearly constant throughout the modulated structures; their variation along the $t$-axis is $<2$ standard deviations (Table 10, Fig. 2, left). By contrast, the four long distances vary along the $t$-axis, depending on the $\mathrm{Ag}$ contribution in the (Au,Ag) position (Fig. 2, left). For the lower $\mathrm{Ag}$ contents (i.e., $\mathrm{Ag}_{0.00}, \mathrm{Ag}_{0.02}$, and $\mathrm{Ag}_{0.05}$ ), this variation points to an additional differentiation of $\mathrm{CN}$ of (Au,Ag): two long distances are essentially shorter and two others are essentially longer than their mean value (Fig. 2, left). Moreover, only two long distances and $\mathrm{CN}=2+2$ can be considered in two symmetrically related ranges along the $t$-axis, $-0.05<t<0.05$ and $0.45<t<0.55$ (gray areas in Fig. 2, left); two additional distances are $>3.1 \AA$. In the remaining ranges, $0.05<t<0.45$ and $0.55<t<0.95$, the coordination number of (Au,Ag) can be considered as $\mathrm{CN}=2+4$ for $\mathrm{Ag}_{0.00}, \mathrm{Ag}_{0.02}$, and $\mathrm{Ag}_{0.05}$. With increasing $\mathrm{Ag}$ content (i.e., $\mathrm{Ag}_{0.09}, \mathrm{Ag}_{0.19}$, and $\mathrm{Ag}_{0.33}$ ), the coordination number of $(\mathrm{Au}, \mathrm{Ag})$ tends to converge to $\mathrm{CN}=$ $2+4$ (Fig. 2, left). According to Schutte and de Boer (1988), the displacive modulation of the atoms resulting in the differentiation of $\mathrm{CN}$ is associated with a valence fluctuation of $\mathrm{Au}^{+}$and $\mathrm{Au}^{3+}$; in addition, the occupation modulation of the $(\mathrm{Au}, \mathrm{Ag})$ position (ordered distribution of Ag) strengthens this valence fluctuation and the $\mathrm{CN}$ differentiation (dashed line graphs in Fig. 2). Our results confirm and complete their conclusion. Indeed, the differentiation of the $\mathrm{CN}$ is associated with a significant differentiation of the bond valence sum calculated for $\mathrm{Au}$ in $\mathrm{Ag}_{0.00}$ (Fig. 2, top right). This differentiation of the bond valence sum disappears consistently with increased randomness of the Ag distribution, so that starting from $\mathrm{Ag}_{0.19}$ the structure loses its modulation character. Hence, one can conclude that randomly distributed $\mathrm{Ag}$ suppresses the valence fluctuation of $\mathrm{Au}^{+}$and $\mathrm{Au}^{3+}$, whereas an ordered distribution reinforces it.

A portion of the incommensurately modulated structures of $\mathrm{Ag}_{0.00}$ and $\mathrm{Ag}_{0.09}$ (present work) is shown in Figure 3, in comparison with the corresponding portion of the incommensurately 
TABLE 9. Final values of the anisotropic displacement parameters $\left(\AA^{2}\right)$ and Fourier amplitudes of the displacive modulation functions

\begin{tabular}{|c|c|c|c|c|c|c|c|}
\hline & Wave & $U_{11}$ & $U_{22}$ & $U_{33}$ & $U_{12}$ & $U_{13}$ & $U_{23}$ \\
\hline & & & & $\mathbf{A g}_{0.00}$ & & & \\
\hline \multirow[t]{3}{*}{$\mathrm{Au}$} & & $0.02294(15)$ & $0.02287(15)$ & $0.02476(15)$ & 0 & $0.00011(8)$ & 0 \\
\hline & $\mathrm{s}, 1$ & 0 & 0 & 0 & 0 & 0 & 0 \\
\hline & $c, 1$ & 0 & 0 & 0 & $-0.0037(4)$ & 0 & $0.0011(3)$ \\
\hline \multirow[t]{4}{*}{ Te } & & $0.020(3)$ & $0.058(4)$ & $0.028(3)$ & $0.014(3)$ & $0.0040(18)$ & $0.022(3)$ \\
\hline & $\mathrm{s}, 1$ & $0.011(4)$ & $-0.007(6)$ & $0.001(5)$ & $-0.015(3)$ & $-0.009(3)$ & $-0.021(4)$ \\
\hline & $c, 1$ & $0.0002(10)$ & $-0.007(2)$ & $-0.0023(12)$ & $0.0006(9)$ & $-0.0021(10)$ & $0.0005(12)$ \\
\hline & & & & $\mathbf{A g}_{0.02}$ & & & \\
\hline \multirow[t]{3}{*}{$\mathrm{Au}$} & & $0.02302(10)$ & $0.02290(11)$ & $0.02576(10)$ & 0 & $0.00012(6)$ & 0 \\
\hline & $\mathrm{s}, 1$ & 0 & 0 & 0 & 0 & 0 & 0 \\
\hline & $c, 1$ & 0 & 0 & 0 & $-0.0031(4)$ & 0 & $0.0023(4)$ \\
\hline \multirow[t]{3}{*}{$\mathrm{Te}$} & & $0.024(4)$ & $0.040(7)$ & $0.024(3)$ & $0.0053(16)$ & $-0.003(2)$ & $0.011(2)$ \\
\hline & $\mathrm{s}, 1$ & $0.005(6)$ & $0.006(10)$ & $0.010(4)$ & $-0.007(2)$ & $0.002(3)$ & $-0.008(3)$ \\
\hline & $c, 1$ & $0.0001(7)$ & $-0.004(2)$ & $-0.0007(6)$ & $0.0015(13)$ & $-0.0010(4)$ & $0.0011(17)$ \\
\hline \multirow[t]{3}{*}{$\mathrm{Au}$} & & $0.02283(9)$ & $0.02252(9)$ & $0.02492(9)$ & 0 & $0.00010(5)$ & 0 \\
\hline & $\mathrm{s}, 1$ & 0 & 0 & 0 & 0 & 0 & 0 \\
\hline & $c, 1$ & 0 & 0 & 0 & $-0.0035(4)$ & 0 & $0.0021(4)$ \\
\hline \multirow[t]{4}{*}{$\mathrm{Te}$} & & $0.036(2)$ & $0.0296(19)$ & $0.0256(16)$ & $0.0070(13)$ & $-0.0049(12)$ & $0.0106(10)$ \\
\hline & $\mathrm{s}, 1$ & $-0.012(3)$ & $0.007(3)$ & $0.006(3)$ & $-0.0074(13)$ & $0.0047(18)$ & $-0.0065(11)$ \\
\hline & $c, 1$ & $-0.0017(9)$ & $-0.0021(13)$ & $-0.0005(5)$ & $0.0006(7)$ & $-0.0006(4)$ & $0.0008(8)$ \\
\hline & & & & $\mathbf{A g}_{0.09}$ & & & \\
\hline \multirow[t]{3}{*}{$\mathrm{Au}$} & & $0.02285(14)$ & $0.0186(4)$ & $0.02564(16)$ & 0 & $0.00025(9)$ & 0 \\
\hline & $\mathrm{s}, 1$ & 0 & 0 & 0 & 0 & 0 & 0 \\
\hline & $c, 1$ & 0 & 0 & 0 & $0.0010(8)$ & 0 & $0.0071(7)$ \\
\hline \multirow[t]{4}{*}{ Te } & & $0.0289(2)$ & $0.0444(3)$ & $0.0318(2)$ & 0 & $-0.00067(17)$ & 0 \\
\hline & $\mathrm{s}, 1$ & 0 & 0 & 0 & $-0.0042(12)$ & 0 & $-0.0075(11)$ \\
\hline & $c, 1$ & 0 & 0 & 0 & $-0.0036(15)$ & 0 & $0.0065(13)$ \\
\hline & & & & $\mathbf{A g}_{0.19}$ & & & \\
\hline $\mathrm{Au}$ & & $0.02285(9)$ & $0.02182(9)$ & $0.02398(9)$ & 0 & $0.00017(6)$ & 0 \\
\hline \multirow[t]{2}{*}{ Te } & & $0.0298(2)$ & $0.0370(2)$ & $0.0304(2)$ & 0 & $-0.0009(1)$ & 0 \\
\hline & & & & $\mathbf{A g}_{0.33}$ & & & \\
\hline $\mathrm{Au}$ & & $0.02293(7)$ & $0.02216(8)$ & $0.02312(7)$ & 0 & $0.00016(5)$ & 0 \\
\hline $\mathrm{Te}$ & & $0.0298(1)$ & $0.0293(1)$ & $0.0294(1)$ & 0 & $-0.00086(8)$ & 0 \\
\hline
\end{tabular}

TABLE 10. The interatomic distances $(\AA)$ and angles $\left(^{\circ}\right)$ in the modulated structures of $\mathrm{Ag}_{0.00}, \mathrm{Ag}_{0.02}, \mathrm{Ag}_{0.05}$, and $\mathrm{Ag}_{0.09}$

\begin{tabular}{|c|c|c|c|c|c|c|c|c|c|c|c|c|}
\hline & \multicolumn{3}{|c|}{$\mathrm{Ag}_{0.00}$} & \multicolumn{3}{|c|}{$\mathrm{Ag}_{0.02}$} & \multicolumn{3}{|c|}{$\mathrm{Ag}_{0.05}$} & \multicolumn{3}{|c|}{$\mathrm{Ag}_{0.09}$} \\
\hline & average & minimal & maximal & average & minimal & maximal & average & minimal & maximal & average & minimal & maximal \\
\hline$\overline{A u-T e^{a}}$ & $2.675(15)$ & $2.671(18)$ & $2.684(12)$ & $2.678(15)$ & $2.673(18)$ & $2.693(12)$ & $2.688(9)$ & $2.682(11)$ & $2.703(8)$ & $2.6942(6)$ & $2.6939(6)$ & $2.6945(7)$ \\
\hline$A u-T e^{b}$ & $2.99(2)$ & $2.87(2)$ & $3.219(16)$ & $3.00(2)$ & $2.89(2)$ & $3.228(17)$ & $3.010(7)$ & $2.890(7)$ & $3.267(5)$ & $2.980(3)$ & $2.904(4)$ & $3.056(4)$ \\
\hline$A u-T e^{c}$ & $2.95(2)$ & $2.870(15)$ & $3.00(2)$ & $2.95(2)$ & $2.826(17)$ & $3.00(3)$ & $2.943(7)$ & $2.796(6)$ & $3.015(7)$ & $2.979(3)$ & $2.904(4)$ & $3.056(4)$ \\
\hline$A u-T e^{d}$ & $2.675(15)$ & $2.671(18)$ & $2.684(12)$ & $2.679(15)$ & $2.673(18)$ & $2.693(12)$ & $2.688(9)$ & $2.682(11)$ & $2.703(8)$ & $2.6942(6)$ & $2.6939(6)$ & $2.6945(7)$ \\
\hline$A u-T e^{e}$ & $2.98(2)$ & $2.87(2)$ & $3.219(16)$ & $3.00(2)$ & $2.89(2)$ & $3.228(17)$ & $3.007(7)$ & $2.890(7)$ & $3.267(5)$ & $2.979(3)$ & $2.904(4)$ & $3.056(4)$ \\
\hline$A u-T e^{f}$ & $2.96(2)$ & $2.870(15)$ & $3.00(2)$ & $2.95(2)$ & $2.826(17)$ & $3.00(3)$ & $2.945(7)$ & $2.796(6)$ & $3.015(7)$ & $2.980(3)$ & $2.904(4)$ & $3.056(4)$ \\
\hline $\mathrm{Te}^{\mathrm{a}}-\mathrm{Au}-\mathrm{Te} \mathrm{e}^{\mathrm{b}}$ & $97.9(6)$ & $96.0(7)$ & $98.7(6)$ & $97.5(6)$ & $95.8(7)$ & $98.2(6)$ & $97.4(3)$ & $95.8(3)$ & $98.2(3)$ & $96.54(8)$ & $95.47(8)$ & $97.60(8)$ \\
\hline $\mathrm{Te}^{\mathrm{a}}-\mathrm{Au}-\mathrm{Te}^{\mathrm{c}}$ & $96.4(6)$ & $96.0(5)$ & $97.1(7)$ & $96.5(6)$ & $96.1(6)$ & $97.6(5)$ & $96.6(3)$ & $96.0(3)$ & $98.1(2)$ & $96.55(8)$ & $95.47(8)$ & $97.60(8)$ \\
\hline $\mathrm{Te}^{\mathrm{a}}-\mathrm{Au}-\mathrm{Te}^{\mathrm{d}}$ & $169.7(7)$ & $169.7(7)$ & 169.7(7) & $168.4(8)$ & $168.4(8)$ & $168.4(8)$ & $166.32(7)$ & $166.32(7)$ & $166.32(7)$ & $178.56(15)$ & 177.72(19) & 180 \\
\hline $\mathrm{Te}^{\mathrm{a}}-\mathrm{Au}-\mathrm{Te}^{\mathrm{e}}$ & $83.8(6)$ & $83.4(5)$ & $83.9(6)$ & $83.4(6)$ & $82.2(5)$ & $84.2(7)$ & $83.3(3)$ & $81.6(3)$ & $84.4(3)$ & $83.43(7)$ & $82.66(7)$ & $84.21(7)$ \\
\hline $\mathrm{Te}^{\mathrm{a}}-\mathrm{Au}-\mathrm{Te}^{\mathrm{f}}$ & $81.7(6)$ & $81.4(6)$ & $82.6(5)$ & $82.2(6)$ & $81.8(6)$ & $83.3(5)$ & $82.3(3)$ & $81.7(3)$ & $83.8(2)$ & $83.44(7)$ & $82.66(7)$ & $84.21(7)$ \\
\hline $\mathrm{Te}^{\mathrm{b}}-\mathrm{Au}-\mathrm{Te}^{\mathrm{d}}$ & $83.8(6)$ & $83.4(7)$ & $83.9(6)$ & $83.4(7)$ & $82.2(7)$ & $84.2(6)$ & $83.3(2)$ & $81.6(3)$ & $84.4(2)$ & $83.44(8)$ & $82.66(8)$ & $84.21(8)$ \\
\hline $\mathrm{Te}^{\mathrm{b}}-\mathrm{Au}-\mathrm{Te} e^{\mathrm{e}}$ & $84.2(6)$ & $83.4(6)$ & $84.7(7)$ & $84.1(7)$ & $82.2(6)$ & $85.1(7)$ & $84.1(2)$ & $81.7(2)$ & $85.5(2)$ & $84.37(9)$ & $81.93(11)$ & $86.86(13)$ \\
\hline $\mathrm{Te}^{\mathrm{b}}-\mathrm{Au}-\mathrm{Te}^{\mathrm{f}}$ & $178.8(6)$ & $177.9(6)$ & $179.9(5)$ & $178.7(6)$ & $176.7(6)$ & $179.9(5)$ & $178.5(2)$ & $176.0(2)$ & $179.9(3)$ & $178.44(9)$ & $177.53(12)$ & 180 \\
\hline $\mathrm{Te}^{\mathrm{c}}-\mathrm{Au}-\mathrm{Te}^{\mathrm{d}}$ & $81.7(6)$ & $81.4(6)$ & $82.6(7)$ & $82.2(7)$ & $81.8(6)$ & $83.3(7)$ & $82.3(2)$ & $81.7(2)$ & $83.8(3)$ & $83.43(8)$ & $82.66(8)$ & $84.21(8)$ \\
\hline $\mathrm{Te}^{\mathrm{c}}-\mathrm{Au}-\mathrm{Te} \mathrm{e}^{\mathrm{e}}$ & $178.8(6)$ & $177.9(6)$ & $179.9(5)$ & $178.7(6)$ & $176.7(6)$ & $179.9(5)$ & $178.5(2)$ & $176.0(2)$ & $179.9(3)$ & $178.44(9)$ & $177.53(12)$ & 180 \\
\hline $\mathrm{Te}^{\mathrm{c}}-\mathrm{Au}-\mathrm{Te}^{f}$ & $82.8(6)$ & $81.1(7)$ & $85.6(6)$ & $83.3(7)$ & $81.7(7)$ & $86.1(6)$ & $83.4(2)$ & $81.6(2)$ & $86.7(2)$ & $84.37(9)$ & $81.93(11)$ & $86.86(13)$ \\
\hline $\mathrm{Te}^{\mathrm{d}}-\mathrm{Au}-\mathrm{Te}^{\mathrm{e}}$ & $97.9(6)$ & $96.0(7)$ & $98.7(6)$ & $97.5(6)$ & $95.8(7)$ & $98.2(6)$ & $97.5(3)$ & $95.8(3)$ & $98.2(3)$ & $96.55(8)$ & $95.47(8)$ & $97.60(8)$ \\
\hline$T e^{d}-A u-T e^{f}$ & $96.4(6)$ & $96.0(5)$ & $97.1(7)$ & $96.5(6)$ & $96.1(6)$ & $97.6(5)$ & $96.6(3)$ & $96.0(3)$ & $98.1(2)$ & $96.54(8)$ & $95.47(8)$ & $97.60(8)$ \\
\hline$T e^{e}-A u-T e^{f}$ & $95.8(6)$ & $92.6(6)$ & $97.3(6)$ & $95.8(6)$ & $93.3(6)$ & $97.3(6)$ & $95.7(2)$ & $93.1(2)$ & $97.4(2)$ & $95.63(8)$ & $95.60(8)$ & $95.66(8)$ \\
\hline
\end{tabular}

Note: Symmetry codes: (a) $x-1, y, z ;$ (b) $x-1 / 2, y-1 / 2, z ;$ (c) $x-1 / 2, y+1 / 2, z$; (d) $-x+1, y,-z$; (e) $-x+1 / 2, y-1 / 2,-z$; (f) $-x+1 / 2, y+1 / 2,-z$.

TABLE 11. Selected bond distances and angles for the average structures of $\mathrm{Ag}_{0.19}$ and $\mathrm{Ag}_{0.33}$

\begin{tabular}{lll}
\hline & $\mathrm{Ag}_{0.19}$ & \\
\hline $\mathrm{Au}-\mathrm{Te}(\times 2)$ & $2.7240(4)$ & $2.7713(3)$ \\
$\mathrm{Au}-\mathrm{Te}(\times 4)$ & $2.9913(3)$ & $3.0105(2)$ \\
mean & 2.902 & 2.931 \\
$\mathrm{Te}-\mathrm{Au}-\mathrm{Te}(\times 4)$ & 180.00 & 180.00 \\
Te-Au-Te $(\times 4)$ & $96.51(1)$ & $96.43(1)$ \\
$\mathrm{Te}-\mathrm{Au}-\mathrm{Te}(\times 4)$ & $83.49(1)$ & $83.57(1)$ \\
$\mathrm{Te}-\mathrm{Au}-\mathrm{Te}(\times 2)$ & $84.60(1)$ & $85.07(1)$ \\
Te-Au-Te $(\times 2)$ & $95.40(1)$ & $94.93(1)$ \\
Te-Te & $3.2490(4)$ & $3.2900(3)$ \\
Te-Te-Te & $85.84(2)$ & $84.79(2)$ \\
\hline
\end{tabular}

modulated structure of $\mathrm{Ag}_{0.1}$ reconstructed using the data of Schutte and de Boer (1988). Distances only shorter than $3.1 \AA$ are shown in this figure. In $\mathrm{Ag}_{0.00}$, the square coordination of $\mathrm{Au}$ (Fig. 3, top) with $\mathrm{CN}=2+2$ and distances $2.67 \AA \times 2$ and $\sim 2.88$ $\AA \times 2$ (gray region in Fig. 2, left-top) is associated with the lower valence fluctuation of $\mathrm{Au}$ (gray region in Fig. 2, right-top). In $\mathrm{Ag}_{0.09}$, the random distribution of $\mathrm{Ag}$ on the (Au, $\left.\mathrm{Ag}\right)$ position leads to a stabilization of the octahedral coordination $(\mathrm{CN}=2+4)$ for all the (Au,Ag) atoms (Fig. 3, middle) and the absence of the valence fluctuation of $\mathrm{Au}$ (Fig. 2, middle-right). This octahedron 


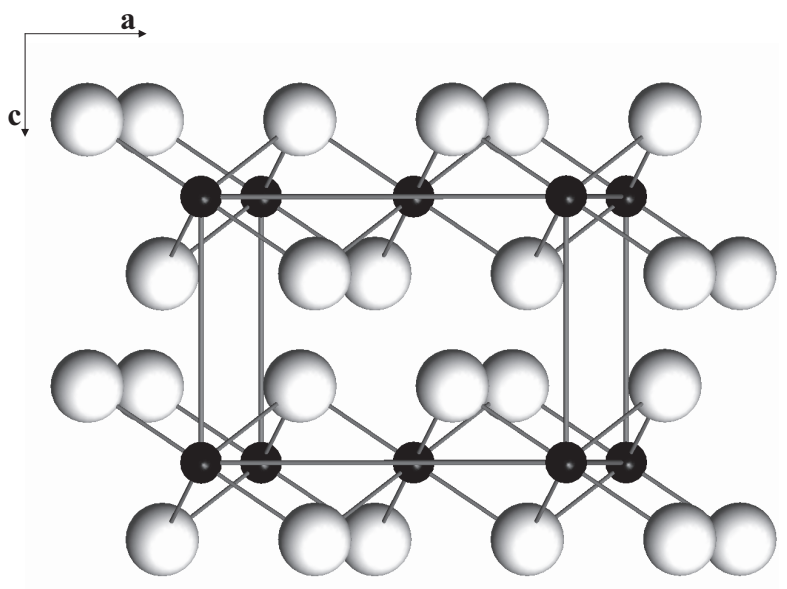

FigURE 1. The crystal structure of calaverite. Black and white spheres refer to the $\mathrm{Au}$ and $\mathrm{Te}$ atoms, respectively. The unit cell and the orientation of the structure are outlined.

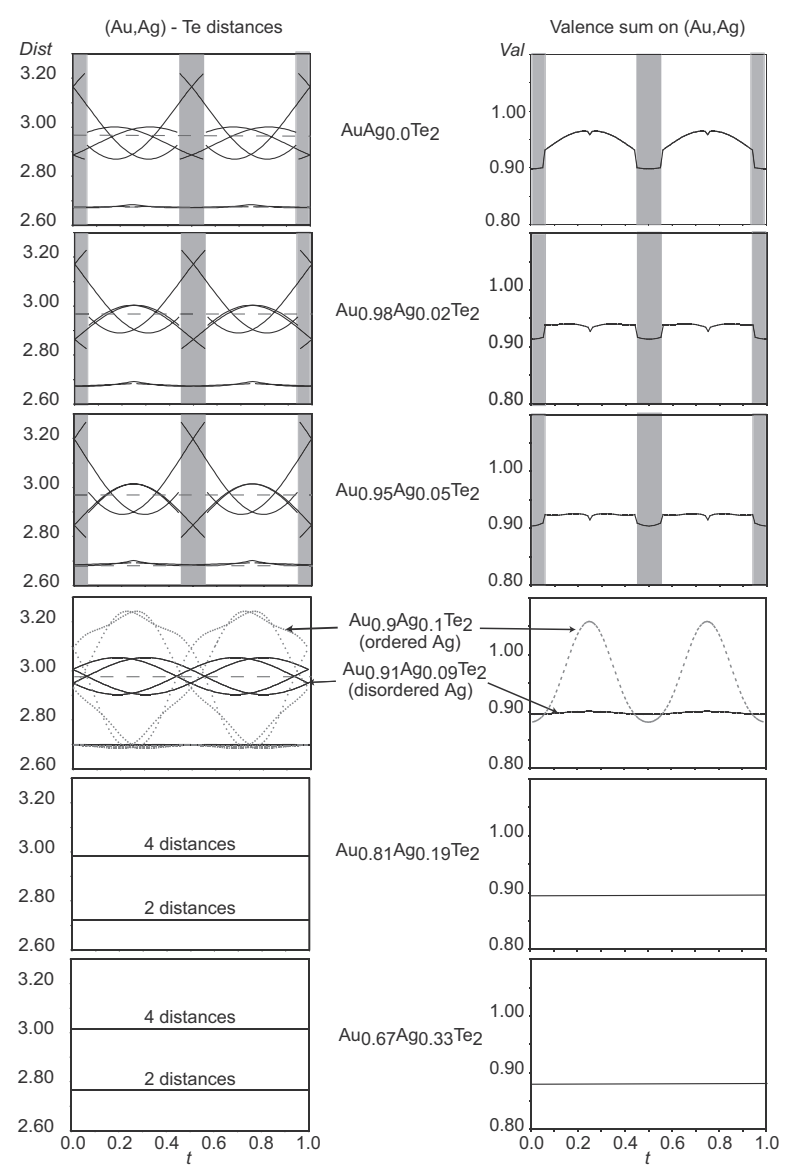

FigURE 2. Variation of the (Au, Ag)-Te distances (left column) and the bond valence sums on ( $\mathrm{Au}, \mathrm{Ag})$ (right column) as functions of $t$. Solid lines correspond to the present work; dashed graphs have been reconstructed using data published by Schutte and de Boer (1988). The gray fields indicate regions with $\mathrm{CN}=2+2$.
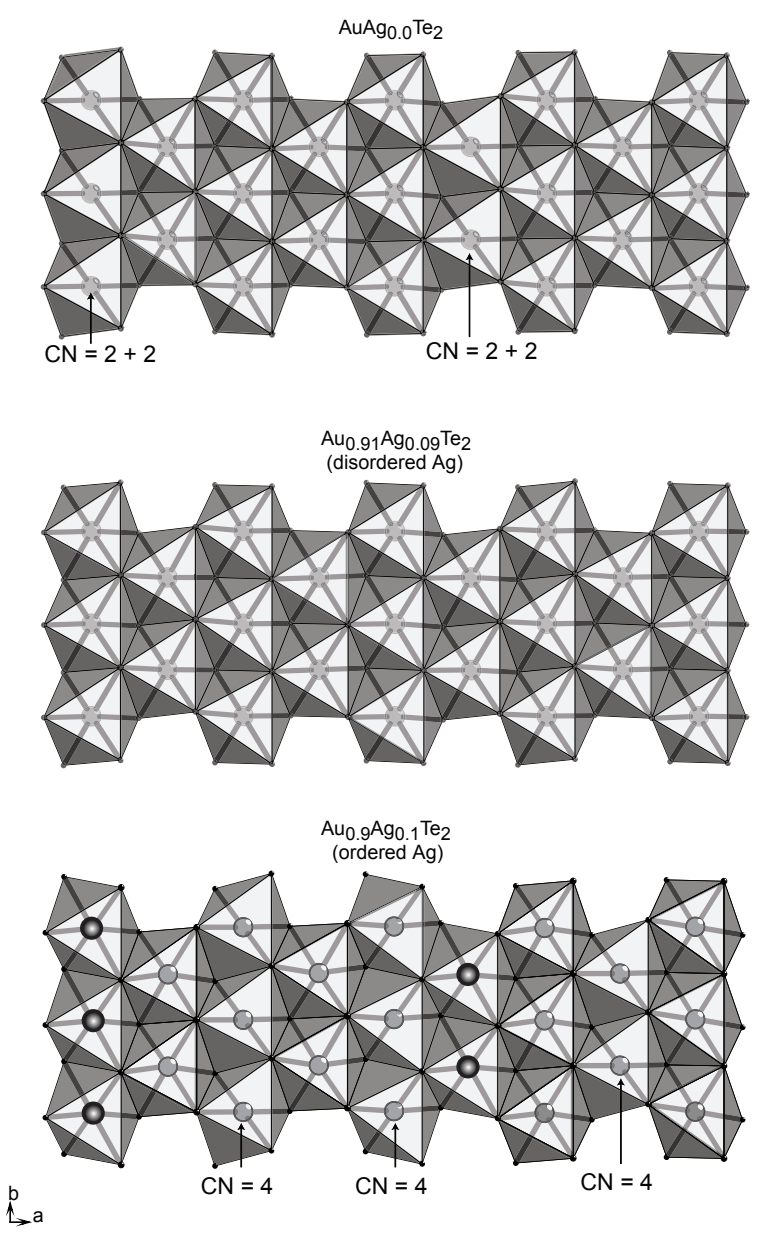

FIGURE 3. [001] projection of a portion of the $\mathrm{Ag}_{0.00}$ and $\mathrm{Ag}_{0.09}$ incommensurately modulated structures (present work) in comparison with the corresponding part of the $\mathrm{Ag}_{0.1}$ structure (Schutte and de Boer 1988). The thick gray lines indicate the (Au,Ag)-Te distances, which are shorter than $3.1 \AA$. The darker circles represent the (Au,Ag) positions that mainly incorporate $\mathrm{Ag}$.

is also characteristic of the ( $\mathrm{Au}, \mathrm{Ag})$ positions that mainly incorporate $\mathrm{Ag}$ in $\mathrm{Ag}_{0.1}$ (darker circles in Fig. 3, bottom). The Ag-free (Au,Ag) positions keep the square coordination (Fig. 3, bottom), and a higher bond valence sum (dashed lines in Fig. 2).

Our investigation of the natural minerals in the series $\mathrm{Au}_{1-\mathrm{x}}$ $\mathrm{Ag}_{\mathrm{x}} \mathrm{Te}_{2}$ completes other studies on calaverite (Pertlik 1984a; Schutte and Boer 1988; Van Tendeloo et al. 1983a; Reithmayer et al. 1993), sylvanite (Van Tendeloo et al. 1983b; Pertlik 1984c), and krennerite (Van Tendeloo et al. 1984; Pertlik 1984b). All these examples taken together show that different degrees of valence fluctuations on the Au-position are possible and, further, these fluctuations can induce the structure modulation.

\section{Variation of the unit-cell parameters and the modulation wave vector}

As shown in Figure 4, the incorporation of $\mathrm{Ag}$ on the octahedral site causes an anisotropic expansion of the unit cell. Both the $a$ and $c$ parameters (Figs. 4a and 4c) increase linearly, 

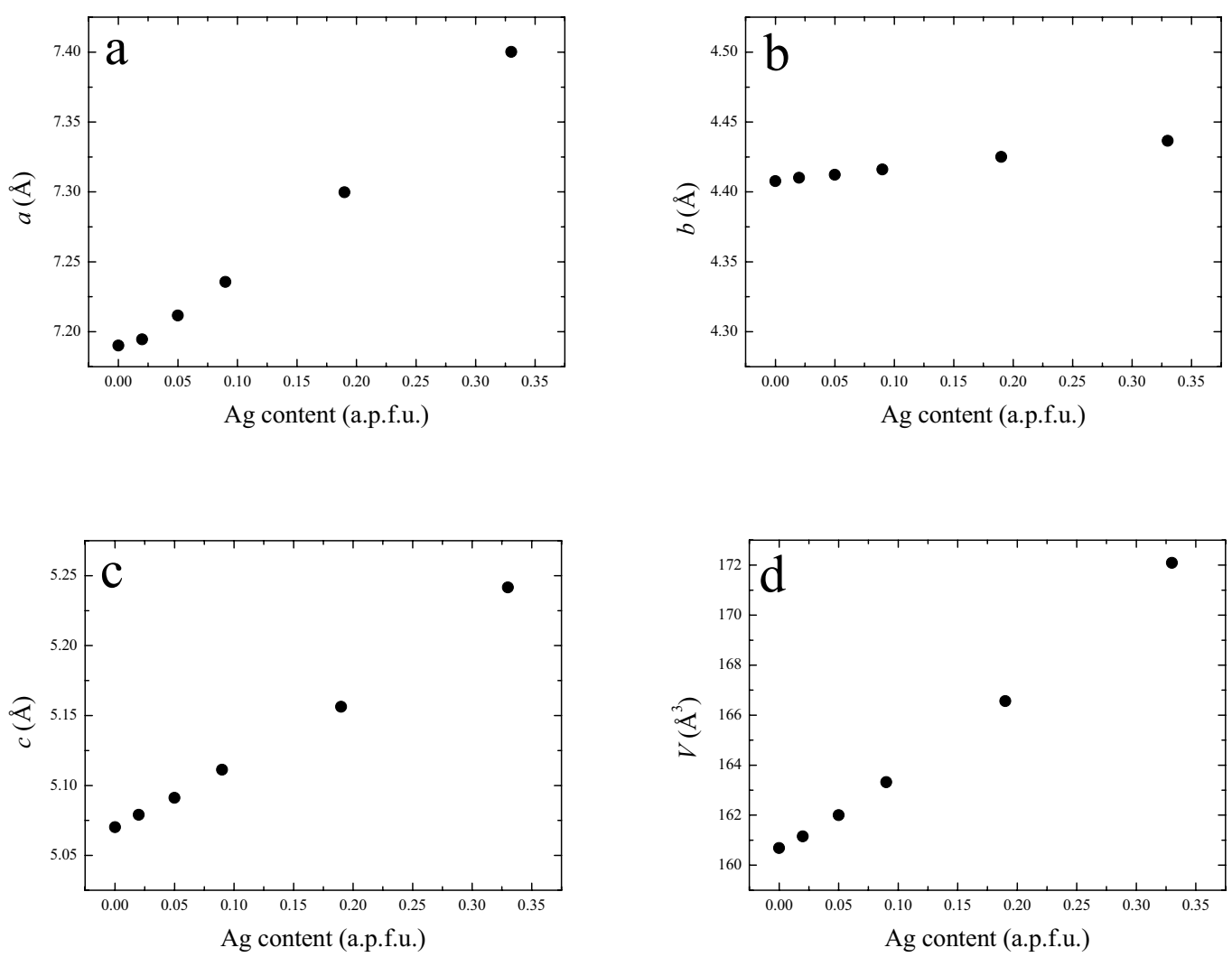

FIGURE 4. Variation of the unit-cell parameters as a function of the Ag content (apfu).

whereas the $b$ parameter remains essentially unchanged (Fig. $4 b)$. No clear trend can be observed for the $\beta$ angle, which does not appear to be related to the Ag content (Table 5). The marked increase of the $a$ and $c$ parameters as a function of $\mathrm{Ag}$ content is mainly related to the pronounced lengthening of the two shortest octahedral distances.

Figure 5 illustrates the variation of the coefficients $\alpha$ and $\gamma$ of the modulation vector as a function of the $\mathrm{Ag}$ content. We observe a constant linear decrease of $\alpha$ and a linear increase of $\gamma$ with increasing the Ag content. The observed variation of the modulation wave vector indicates that for the samples of calaverite studied here no characteristic phase with a specific $\mathbf{q}$ is observed. Furthermore, the variations in the modulation wave vector (Table 5) are larger than those observed by Balzuweit et al. (1993) for synthetic Ag-bearing calaverites.

\section{The calaverite $(3+1) D$ structure-type family}

It is remarkable that calaverite, krennerite, sylvanite, and related compounds can be described within a unique $(3+1) \mathrm{D}$ structure-type, similar to another large group of related compounds jointly described within the scheelite $(3+1) \mathrm{D}$ structuretype (Arakcheeva and Chapuis 2008). This "calaverite $(3+1) \mathrm{D}$ structure type" is characterized by: (1) the $(3+1)$-dimensional superspace group $C 2 / m(\alpha 0 \gamma) 0 s$ with the vector $\mathbf{q}=\alpha \mathbf{a}^{*}+\gamma \mathbf{c} *$; (2) unit-cell parameters $a \approx 7.3 \AA, b \approx 4.3 \AA, c \approx 5.1 \AA$, and $\beta \approx$ $90^{\circ}$; and (3) two Wyckoff positions, $A(\mathrm{Au}, \mathrm{Ag})-2 a$ : (000) and $B$ (Te) $4 i$ : $(x 0 z)$. The coefficients of the $\mathbf{q}$ vector and modulation functions of both $A$ and $B$ (both positional and occupational) as well as the variable coordinates of the $B$ position are independent variables. Moreover, the incommensurately modulated structure of calaverite (Schutte and de Boer 1988) can be considered as the parent structure for the starting model of the structure refinements (as has been done in the present work), or for the generation of some related structures. For example, the structure of sylvanite can be derived from calaverite with the rational coefficients of $\mathbf{q}$ $=1 / 2 \mathbf{a}^{*}+0 \mathbf{c}^{*}$ and an occupation function of $A$ position defined by $\mathrm{Ag}$ in the symmetrically related intervals $-0.125<t<0.125$ and $0.375<t<0.625$ and by Au in the symmetrically related intervals $0.125<t<0.375$ and $0.625<t<0.875$. The mineral kostovite $\left(\mathrm{CuAuTe}_{4}\right.$; Van Tendeloo and Amelinckx 1986) is isostructural with sylvanite and can also be included in the calaverite $(3+1)$ $\mathrm{D}$ family. The structure of krennerite, $\mathrm{Ag}_{0.2} \mathrm{Au}_{0.8} \mathrm{Te}_{2}$, can be described as calaverite with ordered twin $m$-mirror planes leading to orthorhombic symmetry (Van Tendeloo et al. 1984). Some synthetic compounds can also be described in the calaverite $(3+1) D$ structure type. For example, the crystal structures of $\mathrm{NbTe}_{2}, \mathrm{TaTe}_{2}$ (Brown 1966), and $\mathrm{VTe}_{2}$ (Bronsema et al. 1984) correspond to this structure type as commensurately modulated structures with $\mathbf{q}=1 / 3 \mathbf{a}^{*}+1 / 3 \mathbf{c}^{*}$.

\section{CONCLUDING REMARKS}

The present study of various calaverite samples with the chemical compositions $\mathrm{Au}_{1-\mathrm{x}} \mathrm{Ag}_{\mathrm{x}} \mathrm{Te}_{2}, 0 \leq \mathrm{x} \leq 0.33$, extends the study of Schutte and de Boer (1988) and sheds new light on 


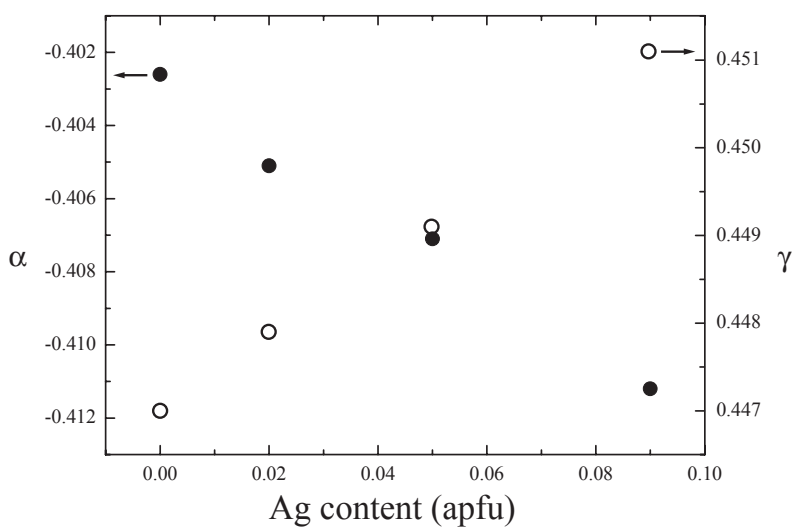

FigURE 5. Variation of the module $\alpha$ and $\gamma$ of the modulation vector as a function of the $\mathrm{Ag}$ content (apfu).

the origin of the structural modulations observed in this family of compounds. Silver atoms present two types of distribution on the Au sites, either randomly distributed or ordered. The original study of Schutte and de Boer (1988) was concerned with an ordered distribution of $\mathrm{Ag}$, which induces very strong valence fluctuations of $\mathrm{Au}$ in the structure. The present study demonstrates another aspect of the $\mathrm{Au}_{1-\mathrm{x}} \mathrm{Ag}_{\mathrm{x}} \mathrm{Te}_{2}$ compounds, specifically those with random distributions of $\mathrm{Ag}$ on the $\mathrm{Au}$ position. By combining the results of both studies, we contend that the valence fluctuation of $\mathrm{Au}$ produces the structure modulation in $\mathrm{AuTe}_{2}$. Moreover, the ordered distribution of silver reinforces the valence fluctuation of $\mathrm{Au}$. A random distribution of $\mathrm{Ag}$ suppresses the valence fluctuation of $\mathrm{Au}$ and, therefore, their structural modulations. Apparently, natural samples can be found with the same composition but with both types of $\mathrm{Ag}$ ordering, which is not surprising considering the various growth conditions of the minerals.

Another interesting aspect of the $\mathrm{Au}_{1-\mathrm{x}} \mathrm{Ag}_{\mathrm{x}} \mathrm{Te}_{2}$ series is related to the $(3+1) \mathrm{D}$ superspace embedding of the calaverite structure type. We have shown that the same model, independently of their 3D structures and periodicities, can describe all the samples with the same general formula. This formalism opens new perspectives, not only for a uniform description of this family of minerals, but also for other synthetic compounds related to the calaverite structure.

\section{ACKNOWLEDGMENTS}

The paper benefited by the official reviews made by P. Spry and an anonymous reviewer. Associate Editor $\mathrm{H}$. Xu is thanked for his efficient handling of the manuscript. This work was funded by M.I.U.R., P.R.I.N. 2007, project "Complexity in minerals: modulation, phase transition, structural disorder" issued to Silvio Menchetti. The support provided by the Swiss National Science Foundation (grant $20-113605)$ is gratefully acknowledged.

\section{REFERENCES CITED}

Ahmad, M., Solomon, M., and Walsh, J.L. (1987) Mineralogical and geochemical studies of the Emperor gold telluride deposit, Fiji. Economic Geology, $82,345-370$.

Alderton, D.H.M. and Fallick, A.E. (2000) The nature and genesis of gold-silvertellurium mineralization in the Metaliferi Mountains of western Romania. Economic Geology, 95, 495-516.

Arakcheeva, A. and Chapuis, G. (2008) Capabilities and limitations of a (3+ d)-dimensional incommensurately modulated structure as a model for the derivation of an extended family of compounds: example of the scheelite-like structures. Acta Crystallographica, B64, 12-25.

Balzuweit, K., Hovestad, A., Meekes, H., and de Boer, J.L. (1993) The temperature and composition dependence of the modulation wave vector of incommensurate calaverite. Journal of Crystal Growth, 131, 518-532.

Bindi, L. (2008) Commensurate-incommensurate phase transition in muthmannite, $\mathrm{AuAgTe} \mathrm{A}_{2}$ : First evidence of a modulated structure at low-temperature. Philosophical Magazine Letters, 88, 533-541.

- (2009) Thermal expansion behavior of empressite, AgTe: A structural study by means of in situ high-temperature single-crystal X-ray diffraction. Journal of Alloys and Compounds, 473, 262-264, DOI: 10.1016/j. jallcom.2008.05.043.

Bindi, L. and Cipriani, C. (2003a) Plumbian baksanite from the Tyrny'auz W-Mo deposit, Baksan River valley, northern Caucasus, Russian Federation. Canadian Mineralogist, 41, 1475-1479.

- (2003b) Crystal structure refinement of winstanleyite, $\mathrm{TiTe}_{3} \mathrm{O}_{8}$, from the Grand Central Mine, Tombstone, Arizona. Canadian Mineralogist, 41, $1469-1473$.

(2004a) Museumite, $\mathrm{Pb}_{5} \mathrm{AuSbTe}_{2} \mathrm{~S}_{12}$, a new mineral from the gold-telluride deposit of Sacarîmb, Metaliferi Mountains, western Romania. European Journal of Mineralogy, 16, 835-838.

- (2004b) Ordered distribution of Au and Ag in the crystal structure of muthmannite, $\mathrm{AuAgTe}$, a rare telluride from Sacarîmb, western Romania. American Mineralogist, 89, 1505-1509.

- (2004c) The crystal structure of skippenite, $\mathrm{Bi}_{2} \mathrm{Se}_{2} \mathrm{Te}$, from the Kochkar deposit, southern Urals, Russian Federation. Canadian Mineralogist, 42, $835-840$.

(2004d) Mazzettiite, $\mathrm{Ag}_{3} \mathrm{HgPbSbTe}_{5}$, a new mineral for the Findley Gulch, Saguache County, Colorado. Canadian Mineralogist, 42, 1739-1743.

Bindi, L., Spry, P.G., and Cipriani, C. (2004) Empressite, AgTe, from the EmpressJosephine Mine, Colorado, U.S.A.: Composition, physical properties and determination of the crystal structure. American Mineralogist, 89, 1043-1047.

Bindi, L., Rossell Abrodos, M., Van Tendeloo, G., Spry, P.G., and Cipriani, C. (2005) Inferred phase relations in part of the system Au-Ag-Te: an integrated analytical study of gold ore from the Golden Mile, Kalgoorlie, Australia. Mineralogy and Petrology, 83, 283-293.

Bronsema, K.D., Bus, G.W., and Wiegers, G.A. (1984) The crystal structure of vanadium ditelluride, $\mathrm{V}_{1+\mathrm{x}} \mathrm{Te}_{2}$. Journal of Solid State Chemistry, 53, 415-421.

Brown, B.E. (1966) The crystal structures of $\mathrm{NbTe}_{2}$ and $\mathrm{TaTe}_{2}$. Acta Crystallographica, B20, 264.

Cabri, L.J.P. (1965) Phase relations in the Au-Ag-Te system and their mineralogical significance. Economic Geology, 60, 1569-1606.

Chapuis, G. (2003) Crystallographic excursion in superspace. Crystal Engineering, 6, 187-195.

Clout, J.M.F., Cleghorn, J.H., and Eaton, P.C. (1990) Geology of the Kalgoorlie gold field. In F.E. Hughes, Ed., Geology of the Mineral Deposits of Australia and Papua New Guinea, p. 411-431. Australian Institute of Mineral Metallography, Melbourne.

Dam, B., Janner, A., and Donnay, J.D.H. (1985) Incommensurate morphology of calaverite $\left(\mathrm{AuTe}_{2}\right)$ crystals. Physical Review Letters, 55, 2301-2304.

Ghent, F.A. (1861) Calaverite. American Journal of Science, 45, 314-317.

Goldschmidt, V., Palache, C., and Peacock, M. (1931) Über calaverit. Neues Jahrbuch für Mineralogie, 63, 1-58.

Ibers, J.A. and Hamilton, W.C., Eds. (1974) International Tables for X-ray Crystallography, IV, 366 p. Kynock, Dordrecht.

Oxford Diffraction (2006) CrysAlis RED (Version 1.171.31.2) and ABSPACK in CrysAlis RED. Oxford Diffraction Ltd, Abingdon, Oxfordshire.

Pals, D.W. and Spry, P.G. (2003) Telluride mineralogy of the low-sulfidation epithermal Emperor gold deposit, Vatukoula, Fiji. Mineralogy and Petrology, 79, 285-300.

Pertlik, F. (1984a) Kristallchemie natürlicher Telluride III: Die Kristallstruktur des Minerals Calaverit, $\mathrm{AuTe}_{2}$. Zeitschrift für Kristallographie, 169, 227-236. (1984b) Crystal chemistry of natural tellurides II: redetermination of the crystal structure of krennerite, $\left(\mathrm{Au}_{1-\mathrm{x}} \mathrm{Ag}_{\mathrm{x}}\right) \mathrm{Te}_{2}$ with $\mathrm{x} \sim 0.2$. Tschermaks Mineralogische und Petrographische Mitteilungen, 33, 253-262.

(1984c) Kristallchemie natürlicher Telluride I: Verfeinerung der Kristallstruktur des Sylvanits, AuAgTe ${ }_{4}$. Tschermaks Mineralogische und Petrographische Mitteilungen, 33, 203-212.

Petř́ček, V., Dušek, M., and Palatinus, L. (2006) JANA2006, a crystallographic computing system. Institute of Physics, Academy of Sciences of the Czech Republic, Prague.

Reithmayer, K., Steurer, W., Schulz, H., and de Boer, J.L. (1993) High-pressure single-crystal study on calaverite, $\mathrm{AuTe}_{2}$. Acta Crystallographica, B49, 6-11.

Schutte, W.J. and de Boer, J.L. (1988) Valence fluctuations in the incommensurately modulated structure of calaverite $\mathrm{AuTe}_{2}$. Acta Crystallographica, B44, 486- 494.

Shackleton, J.M., Spry, P.G., and Bateman, R. (2003) Telluride mineralogy of the Golden Mile deposit, Western Australia. Canadian Mineralogist, 41, $1503-1524$. 
Sueno, S., Kimata, M., and Ohmasa, M. (1979) Modulated Structures 1979. In J.M. Cowley, J.B. Cohen, M.B. Salamon, and J. Wuench, Eds., AIP Conference Proceedings, 53, p. 333. American Institute of Physics, New York.

Thompson, T.B., Trippel, A.D., and Dwelley, P.C. (1985) Mineralized veins and breccias of the Cripple Creek district, Colorado. Economic Geology, 80, 1669-1688.

Tunell, G. and Ksanda, C.J. (1936) The crystal structure of krennerite. Journal of Washington Academy of Sciences, 26, 509-528.

Tunell, G. and Pauling, L. (1952) The atomic arrangement and bonds of the goldsilver ditellurides. Acta Crystallographica, 5, 375-381.

Van Tendeloo, G. and Amelinckx, S. (1986) High-resolution electron-microscopic study of the modulated structure of kostovite $\left(\mathrm{Cu}_{1-x} \mathrm{Au}_{1+x} \mathrm{Te}_{4}\right)$. Acta Crystallographica, B42, 121-130.

Van Tendeloo, G., Gregoriades, P., and Amelinckx, S. (1983a) Electron microscopy studies of modulated structures in $(\mathrm{Au}, \mathrm{Ag}) \mathrm{Te}_{2}$ : Part I. Calaverite $\mathrm{AuTe}_{2}$. Journal of Solid State Chemistry, 50, 321-334

(1983b) Electron microscopic studies of modulated structures in (Au,Ag)Te $\mathrm{Te}_{2}$ : Part II. Sylvanite $\mathrm{AgAuTe}_{4}$. Journal of Solid State Chemistry, 50, 335-361.

Van Tendeloo, G., Amelinckx, S., and Gregoriades, P. (1984) Electron microscopic studies of modulated structures in (Au,Ag) $\mathrm{Te}_{2}$ : III. Krennerite. Journal of Solid State Chemistry, 53, 281-289.

MANUSCRIPT RECEIVED NOVEMBER 25, 2008

MANUSCRIPT ACCEPTED FEBRUARY 2, 2009

MANUSCRIPT HANDLED BY HONGWU XU 